$\xi=$

\title{
Assessment of visual, auditory, and kinesthetic learning style among undergraduate nursing students
}

\author{
Radhwan Hussein Ibrahim ${ }^{1 *}$, Dhia-Alrahman Hussein ${ }^{2}$ \\ ${ }^{1}$ College of Nursing, University of Mosul \\ ${ }^{2}$ College of Nursing, University of Kirkuk \\ *Corresponding author E-mail: radh_huss@yahoo.com
}

\begin{abstract}
Background: Learning styles refer to the ability of learner to perceive and process information in learning situations. The ability to understand students' learning styles can increase the educational outcomes. VAK (Visual, auditory, kinesthetic) learning style is one of the learning style in which students use three of sensory perception to receive information. Teachers can incorporate these learning styles in their classroom activities so that students are competent to be successful in their courses. The purpose of this study is to assess Visual, Auditory, and Kinesthetic learning style among undergraduate nursing students.

Methods: A descriptive study was carried out; the study was conducted during the period of 3rd. November, 2013-15, March, 2014, in two Nursing Colleges at Universities of Mosul and Kirkuk. A stratified random sampling was used for data collection. The target population was an undergraduate nursing students (210) students (60 male and 150 female). Statistical Package for the Social Science (SPSS), Chi-square, Frequencies and Percentage was used for data analysis.

The results: the findings reveal that Visual, Auditory, and Kinesthetic learning style of the study sample was (40.0\%), (29.5\%), and 30.5\% respectively. Females preferred auditory learning style (30.3\%) more than males $(27.3 \%)$, while males preferred kinesthetic learning style $(32.3 \%)$ more than females $(29.8 \%)$.

Recommendation: The researcher recommended that nurse educators should aware of learning styles of the students and provide teaching style to be matched with their learning style.
\end{abstract}

Keywords: Nursing; Visual; Auditory; and Kinesthetic Learning Style.

\section{Introduction}

Learning style is a broad concept playing an important role in the classroom education outcomes. Students' favorites and style to their own learning play an important role in educational consequences and these favorites are conveyed into different learning styles (Leung \& Weng, 2007). Learning is defined as the process whereby knowledge is formed into the transformation of experience. People use learning to adapt to and achieve everyday conditions, giving to increase to diverse styles of learning. The concept of learning styles has received huge attention in the pragmatic texts and various models have been suggested in order to enhanced appreciate the active manner of teaching (Arthurs, 2007). A variety of learning style theories and frameworks have been developed along with accompanying instruments that operationalize their learning style constructs (Dunn \& Griggs, 2003; Loo, 2004). Evaluating students' learning styles offers awareness about their specific favorites. This awareness can be used to develop, design, format, and deliver educational programs and resources that will motivate and stimulate students' gaining, integration, and application of information and professional knowledge in an attempt to individualize instruction. "Understanding styles can improve the planning, producing, and implementing of educational experiences, thus they are more suitably harmonious with students' wishes, in order to improve their learning, retention and retrieval" (Federico, 2000).

\section{Objectives of the study}

1. To assess undergraduates nursing students' preferred learning styles

2. To identify the relationship between some characteristics of students with visual, auditory, and kinesthetic learning styles like their gender and academic level

\section{Methods}

\subsection{Ethical issues}

Prior of the data collection, formal administrative approval was obtained to conduct the study from College of Nursing / University of Mosul and College of Nursing / University of Kirkuk.

\subsection{Design of the study}

A non-experimental study was conducted during the period of $3 \mathrm{rd}$. November, 2013- 15, March, 2014 using a descriptive design was applied in the present study to assess visual, auditory, and kinesthetic learning style among undergraduate nursing students 


\subsection{Setting of the study}

The study conducted in two Nursing Colleges at Universities of Mosul and Kirkuk. College of Nursing / University of Mosul established in 1993. The college has B.ScN and MScN. College of Nursing / University of Kirkuk established in 2002 and was affiliated to the presidency of the University of Mosul and then continues to follow the University of Kirkuk after 2003.

\subsection{Study population}

The target population includes the (1040) undergraduate nursing students' females and males, studied in all academic year.

\subsection{Sample of the study}

The sample size in the current study was (210) samples, selected from 1040 students from each college. The sample was selected by stratified random sampling technique; the researcher was selecting the sample according to the table name of the students. Table 4.1 describes the distribution of the students according to the gender and stages.

\subsection{Tools of the study}

In order to collect the study information, a VAK Learning style self-administration questionnaire developed by Victoria Chislett \& Alan Chapman, 2005) was used. .It is composed of two parts:-

Part one: - This part included (5) items which focus on the students demographic characteristics such as (age, sex, class,).

Part two: - VAK learning style questionnaire. A selfadministration questionnaire composed of 30 multiple choice questions. The overall questions include three options (A, B, and C). Option a represent Visual learning style, option B represent auditory learning style, and option $\mathrm{C}$ represent kinesthetic learning style.

\subsection{Validity of the tool}

The validity of the instrument was established through a panel of (15) experts of different specialties related to the field of the present study. They were asked respectively to review the questionnaire for clarity and adequacy in order to achieve the present study objective. These experts were asked to review the questionnaire for content clarity, relevancy and adequacy. Their responses indicated that minor changes should be done too few items. Such changes were made according to their suggestions and valuable comments.

\subsection{Reliability}

Reliability of the questionnaire was determined through the use of test-retest approach. Pearson Correlation Coefficients were computed. The reliability of Visual learning style was (0.860), Auditory learning style (0.808), and Kinesthetic learning style (0.752).

\subsection{Data collection procedure}

The data collection process was started by inviting students to share in this study and only those who agreed were included in the study. The process was finished in three months at the Nursing College/ University of Mosul and Nursing College/ University of Kirkuk. The students were given the VAK learning style questionnaire where they took approximately between 20-25 minutes to complete the questionnaire this determined during the pilot study. The researcher who randomly collects the data from the selected sample. The researcher firstly describes the aim of the study for the students and some explanation of any items in the questionnaire. The period of the study was from 18th February 2015 to the 15th of March 2015.

\subsection{Data analysis}

Data are prepared, organized and entered into a computer file; Different statistical methods were used to analyze the data in this study. Statistical processing was conducted by the use of SPSS version 17. Frequency and percentage of variables were used. Chisquare test was used as the test of significance to determine the presence of association between variables.

\section{Results}

The finding that presented in Table (4-1) described study subject, $(32.9 \%)$ from Kirkuk Nursing college and $(67.1 \%)$ from Mosul Nursing College, $(28.6 \%)$ of them were male, and $(71.4 \%)$ were female. Also the table shows that $(25.2 \%)$ of the student in first stage, $(30.1 \%)$ in second stage, $(17.6 \%)$ in third stage, and $(27.1 \%)$ in forth stage. Table (4-2) shows the Visual learning style in Nursing College/ University of Mosul is (40.4\%), (30.0\%) is Auditory learning style, and $(29.6 \%)$ is kinesthetic learning style. Visual learning style in Nursing College/ University of Kirkuk is (39.9\%), (29.2\%) is Auditory learning style, and (30.9\%) is Kinesthetic learning style. Visual learning style for Male is $(40.4 \%)$, $(27.3 \%)$ is Auditory learning style, and $(32.3 \%)$ is Kinesthetic learning style. Visual learning style for female is (39.9\%), (30.3\%) is Auditory learning style, and (29.8\%) is Kinesthetic learning style Table (4-3). Visual learning style for first class is (40.4\%), $(29.4 \%)$ is Auditory learning style, and $(32.2 \%)$ is Kinesthetic learning style. Visual learning style for second class is $(40.2 \%)$, $(27.2 \%)$ is Auditory learning style, and $(32.6 \%)$ is Kinesthetic learning style. Visual learning style for third class is $(38.7 \%)$, $(29.7 \%)$ is Auditory learning style, and $(31.6 \%)$ is Kinesthetic learning style. Visual learning style for forth class is (40.4\%), $(31.8 \%)$ is an auditory learning style, and $(27.8 \%)$ is a kinesthetic learning style. Table (4-4).

Table 4.1: Distribution of Demographical Data of the Study Sample.

\begin{tabular}{llll}
\hline Variables & & No. & $\%$ \\
\hline \multirow{2}{*}{ University } & Kirkuk & 69 & 32.9 \\
Total & Mosul & 141 & 67.1 \\
\multirow{2}{*}{ Gender } & Male & 210 & 100 \\
& Female & 60 & 28.6 \\
& & 150 & 71.4 \\
Classes & First class & 210 & 100 \\
& Second class & 53 & 25.2 \\
Total & Third class & 63 & 30.1 \\
& Forth class & 37 & 17.6 \\
& & 57 & 27.1 \\
\end{tabular}

Table 4.2: Comparison of Nursing Colleges at Universities of Mosul and Kirkuk about VAK Learning Style

\begin{tabular}{lllll}
\hline \multirow{2}{*}{ VAK } & Kirkuk & \multicolumn{3}{c}{ Mosul } \\
& F. & $\%$ & F. & $\%$ \\
\hline Visual learning style & 826 & 40.4 & 1695 & 39.9 \\
Auditory learning style & 615 & 30.0 & 1241 & 29.2 \\
Kinesthetic learning style & 605 & 29.6 & 1318 & 30.9 \\
Total & 2046 & 100 & 4254 & 100 \\
\hline
\end{tabular}

Table 4.3: Comparison between Male and Female about VAK Learning Style

\begin{tabular}{lllll}
\hline \multirow{2}{*}{ VAK learning style } & Male & & Female \\
& F. & $\%$ & F. & $\%$ \\
\hline Visual learning style & 728 & 40.4 & 1793 & 39.9 \\
Auditory learning style & 492 & 27.3 & 1364 & 30.3 \\
Kinesthetic learning style & 582 & 32.3 & 1341 & 29.8 \\
Total & 1802 & 100 & 4498 & 100 \\
\hline
\end{tabular}


Table 4.4: Distribution the Frequency and Percent of VAK Learning Style According to Their Classes

\begin{tabular}{|c|c|c|c|c|c|c|c|c|}
\hline \multirow{2}{*}{$\begin{array}{l}\text { VAK } \\
\text { learning } \\
\text { style }\end{array}$} & \multicolumn{2}{|l|}{ First } & \multicolumn{2}{|c|}{ Second } & \multicolumn{2}{|c|}{ Third } & \multicolumn{2}{|l|}{ Forth } \\
\hline & F. & $\%$ & F. & $\%$ & F. & $\%$ & F. & $\%$ \\
\hline $\begin{array}{l}\text { Visual } \\
\text { learning } \\
\text { style }\end{array}$ & 630 & 40.4 & 748 & 40.2 & 452 & 38.7 & 692 & 40.4 \\
\hline $\begin{array}{l}\text { Auditory } \\
\text { learning } \\
\text { style }\end{array}$ & 459 & 29.4 & 506 & 27.2 & 348 & 29.7 & 543 & 31.8 \\
\hline $\begin{array}{l}\text { Kinesthetic } \\
\text { learning } \\
\text { style }\end{array}$ & 472 & 30.2 & 606 & 32.6 & 369 & 31.6 & 475 & 27.8 \\
\hline Total & 1561 & 100 & 1860 & 100 & 1169 & 100 & 1710 & 100 \\
\hline
\end{tabular}

\section{Discussion}

In general, the most student preferred and favorite Visual learning style. It may be the Visual learning style more easy for the students, more attractive, and less power required, While $(30.5 \%)$ of student preferred Kinesthetic ; we believed that they like to move and using touch sensation for acquiring information especially in nursing practice. Auditory style was preferred by $29.5 \%$ of student, they like to sit in calm classroom and listen to the teacher, less power required. It seems that this findings disagreement with a study conducted by Frankel A. (2009) who's reported that Visual, Auditory, and Kinesthetic learning style revealed as $54.0 \%$, $26.9 \%$, and $19.1 \%$ respectively. Also, these results disagreement with Rajshree S. (2013) study, which conducted on secondary school students. Visual, Auditory, and Kinesthetic learning style observed as $(33.5 \%),(28.5 \%)$, and $(38.0 \%)$ respectively. Also, the study of Leslie (2007), showed that the learning style among the adult learners was (34\%) of the participants have visual preferences, $34 \%$ have auditory, $23 \%$ have kinesthetic, and $9 \%$ have multimodal learning preferences, and that younger learners prefer kinesthetic learning style more than adult learners. Additionally, the study conducted by Shah A., et al (2013), in the Department of Oral Medicine and Radiology of two dental colleges, one in Mangalore, Karnataka and the other in Ahmadabad, Gujarat, on (49) students (23 males and 26 females) shows that they preferred unimodal learning. Among the unimodal learners $2(0.3 \%)$ students preferred visual learning style, $17(36.5 \%)$ preferred auditory learning style, $7(11.1 \%)$ preferred read-write learning style and $23(49.2 \%)$ preferred kinesthetic mode of learning. 152 students (74 males and 78 females) $70.7 \%$ ) preferred multimodal learning. Among the multimodal learners $38(25 \%)$ students preferred bimodal learning, 37 (24.3\%) preferred trimodal learning and 77 $(50.66 \%)$ preferred quad modal learning. The finding that presented in Table (4-6) shows that there is no significant difference between Nursing College / University of Kirkuk and Nursing College/ University of Mosul at P-Value $(\leq 0.05)$ this mean that the students in two Nursing College have similar learning style preferences. Individuals differ by gender. Learning style differs between Males and females. Males tend to be more kinesthetic, and visual, and need more mobility in a more informal environment than females. Males tend to learn less by listening. Females more than males tend to be auditory, sit at classroom desks and chairs. Females also tend to be more quiet while teaching (Tatarintseva A., 2002). The results showed that $(54 \%)$ of the female respondents and only $(12.5 \%)$ of the males preferred a single learning style. Among the female respondents, $4.2 \%$ were visual learners, $16.7 \%$ preferred textual learning materials and $33.3 \%$ were kinesthetic learners. Within males, learning styles were evenly distributed among aural, read/write and kinesthetic styles. Several studies showed that there is a difference between learning style preferences in relation to gender. According to Raddon (2007) gender is considered as one of a effective factor in learning style preferences. A study by Wehrwin et al. (2007) was conducted to explore differences between male and female undergraduate physiology students in terms of learning style preferences. The researcher adopted the VARK learning model as a framework and used a VARK questionnaire as the measure to collect data. The study conducted by Erica A. et al. (2007), determined that there are different types of learning styles in the teaching space and that the gender is effective factor in selecting learning styles. Another study conducted by Alkhasawneh, I., et al. (2008) aimed to describe learning styles of third year nursing students in Jordan's public university using the VARK questionnaire. The results showed no significant difference between the learning style preferences of male and female nursing students. Ramayah (2009) conducted a study concerning the learning styles of both male and female students in Malaysia. 207 males and 199 females were involved. The result revealed that the preferred learning styles were the aural and the visual, but has no influence on read and write and kinesthetic ones. The females preferred the visual and aural learning styles more than the males. Lincoln et al (2006) investigated the differences between 33 male and 66 female students based on the VARK framework. The study used ANOVA to further verify that there is a significant difference between the learning style preferences of male and female learners. Also the result indicated that female learners preferred to learn by using their auditory senses while male learn best when note taking (read/write learning styles).Also, these results of the present study agreement with a study conducted by Lincoln, et al., (2006) the study investigated differences between 33 male and 66 female students based on the VARK framework. The study used ANOVA to further verify that there is a significant difference between the learning style preferences of male and female learners. The result also indicated female learners preferred to learn using their auditory senses while male learners learn best when note taking (read/write learning styles). Learning styles change with life progress. Students' learning styles differ between elementary and middle school and between middle school and high school. They continue to change in college and during adulthood, and the styles of older adults in the 65-85 year-old range differ in many ways from those of younger people. Nevertheless, individuals change in unique ways. Some people hardly change their learning style but others experience rapid and multiple changes. (Tatarintseva A., 2002). Table (4-5) shows that the majority of first stage student, second stage and third stage preferred visual learning style then kinesthetic, and auditory. In comparing with study of Terri A. (2009), which conducted on first year nursing students in Australia, the majority of them prefer kinesthetic modes of information presentation, Kinesthetic learners prefer the hands on approach to learning, or learn by doing. Aqel. A, and Mahmoud, S. (2006), conducted a study about learning style for University students, The results showed that there were significant differences in the learning styles according to academic level. This implies that each academic level has its own properties and learning preferences which the lecturer should consider while teaching. In order to adopt different learning styles in the classroom, lecturers must to take into consideration for example that auditory students prefer more listening to the lectures and seminars, and participating in discussions. These students like to listen to the tape recordings of material and have a chance to ask questions about what they have learned or do not understand.

\section{Conclusion}

1) The most preferred learning style of the Nursing students in our study is Visual, then Kinesthetic, and Auditory.

2) There is a significant difference between male and female regarding VAK learning style, male students preferred learning style is Visual, Kinesthetic, and Auditory learning style, while female students preferred learning style is Visual, Auditory, and Kinesthetic learning style.

3) There is a significant difference between classes regarding VAK learning style 


\section{Recommendation}

1) Learners, according to the VAK learning style theory, can be divided into three learners: visual learner, auditory learner, kinesthetic learner. Therefore, the curriculum should include all tools, materials, texts and activities that match all learning styles of students in the classroom.

2) Further study is undertaken regarding the learning styles of nursing students in Iraq.

\section{Acknowledgement}

The authors would like to acknowledge the students who took part in this study and to the Deanship of Nursing College at Universities of Mosul and Kirkuk

\section{References}

[1] Akplotsyi, R. \& Mahdjoubi, L. (2011). Effects of learning styles on engaging children in school projects. 2011, Bristol, UK. Available at website http://www.arcom.ac.uk/publications/procs/ar2011

[2] Alkhasawneh, I., Mrayyan, M., Docherty, C., Alashram, S. \&Yousef, H. (2008).Problem-based learning (PBL): assessing student learning preferences using vark. Nurse Education Today, 28, pp: 572-579. http://dx.doi.org/10.1016/j.nedt.2007.09.012.

[3] Aqel. F. \& Mahmoud, S. (2006). Learning Styles of An-Najah National University Students in Learning English as a Foreign Language. An - Najah Research Journal. (20)2, pp: 598-622.

[4] Arthurs, J. (2007). A juggling act in the classroom: Managing different learning styles. Teaching and Learning in Nursing, 2, 2-7. http://dx.doi.org/10.1016/j.teln.2006.10.002.

[5] Dunn, R., Burke, K., and Whitley, J., (2000) what do know abou learning style? A guide for parents of talented children. Parenting for high potential, 8-13.

[6] Erica A., Heidi L. \& Stephen E.,(2007). Gender differences in learning style preferences among undergraduate physiology students. Advance Physiology Education; (31), pp: 153-157.

[7] Federico, A. (2000). Learning styles and student attitudes toward various aspects of network based instruction. Computers in Human Behavior, 16(4), 359-379. http://dx.doi.org/10.1016/S0747 5632(00)00021-2.

[8] Fleming, S. (2010). "Undergraduate nursing students' learning styles: A longitudinal study". Nurse Education Today. 31(5): pp: 444-449 http://dx.doi.org/10.1016/j.nedt.2010.08.005.

[9] Frankel, A., (2009). Nurses' learning styles: promoting better integration of theory into practice. Nursing Times journal; 105: 2, pp: 24-27.

[10] Leung, K., \& Weng, L. (2007). Validation of Kolb's structura model of experiential learning using Honey and Mumford's Learning Style Questionnaire. Journal of Medical Education, vol.11,p 234-243

[11] Lincoln, F., \& Rademacher, B., (2006) Learning styles of ESL students in community colleges'. Community Journal of Research and Practice, vol. 30(5), pp: 485-500. http://dx.doi.org/10.1080/10668920500207965.

[12] Loo, R., (2004) Kolb's learning styles and learning preferences: is there a linkage? Educational Psychology, vol. 24, 99-108. http://dx.doi.org/10.1080/0144341032000146476.

[13] Raddon, A. (2007). Distance learners jugging home, work and study. In P, Cotterill, S, Jackson, G, Letherby. (Eds.). Challenges and negotiations for women in higher education (pp. 159-181) Dordrecht, the Netherlands: Springer.

[14] Rajshree S., (2013). learning style and academic achievement of secondary school students, voice of research, Vol.1 Issue 4, p:2

[15] Ramayah, M., Sivanandan, L., Nasrijal, N., Letchumanan, T., \& Leong, L. (2009) Preferred learning style: gender influence on preferred learning style among business students. Journal of US-China Public Administration, 6(4), pp.: 65-78.

[16] Shah K., Ahmed J., Shenoy N, Srikant N.,(2013) How different are students and their learning styles? International Journal of Research in Medical Sciences, vol. (1) issue (3), 121-215.

[17] Tatarintseva A., (2002). The Influence of the Gender Factor to the Learning styles of Secondary Students in the Process of Language Learning, studies about languages, vol. 2, p: 65.
[18] Terri A., (2009). Teaching mode efficiency and learning preferences of first year nursing students. Nurse Education Today, vol. (29), p: 24-32.

[19] Victoria, C. and Alan, C.(2005).VAK learning styles selfassessment questionnaire, from [online] Available from World Wide Web www.businessballs.com.

[20] Wehrwein, E., Lujan, H., \& DiCarlo, S., (2007). Gender difference in learning style preferences among undergraduate physiology student. Advances in Physiology Education, vol. (31), p: 153-175. 